A Book I Value 



\title{
Samuel Taylor Coleridge
}

\section{A Book I Value \\ Selected Marginalia}

\author{
EDITED BY
}

H. J. Jackson 
Copyright (C) 2003 by Princeton University Press

Published by Princeton University Press,

41 William Street, Princeton, New Jersey 08540

In the United Kingdom: Princeton University Press, 3 Market Place, Woodstock, Oxfordshire OX20 1SY

All Rights Reserved

Library of Congress Cataloging-in-Publication Data

Coleridge, Samuel Taylor, 1772-1834.

A book I value : selected marginalia / Samuel Taylor Coleridge ; edited by H. J. Jackson.

p. cm.

Includes index.

ISBN 0-691-11351-3 (alk. paper) -

ISBN 0-691-11317-3 (pbk. : alk. paper)

1. Coleridge, Samuel Taylor, 1772-1834-Books and reading.

2. Books and reading. 3. Marginalia. I. Jackson, H. J.

II. Title.

PR4472 .J28 2003

$821^{\prime} .7-\mathrm{dc} 21 \quad 2002074981$

British Library Cataloging-in-Publication Data is available

This book has been composed in Times New Roman

with Perpetua display

Printed on acid-free paper. $\infty$

www.pupress.princeton.edu

Printed in the United States of America

13579108642 
FOR ELIZABETH WHALLEY 
